\title{
CHARACTERISTICS OF CELLPHONES REVERSE LOGISTICS IN CANADA
}

\author{
by \\ Reaz Noman \\ Bachelor of Science in Engineering (Mechanical), \\ Bangladesh University of Engineering \& Technology, 1992
}

An MRP presented to Ryerson University in partial fulfillment of the requirements for the degree of Master of Engineering in the program of Mechanical and Industrial Engineering

Toronto, Ontario, Canada, 2018

(c) Reaz Noman, 2018 


\section{AUTHOR'S DECLARATION}

I hereby declare that I am the sole author of this MRP. This is a true copy of the MRP, including any required final revisions.

I authorize Ryerson University to lend this MRP to other institutions or individuals for the purpose of scholarly research.

I further authorize Ryerson University to reproduce this MRP by photocopying or by other

means, in total or in part, at the request of other institutions or individuals for the purpose of scholarly research.

I understand that my MRP may be made electronically available to the public. 


\section{Abstract \\ CHARACTERISTICS OF CELLPHONES REVERSE LOGISTICS IN CANADA}

Master of Engineering, 2018

Reaz Noman

Mechanical and Industrial Engineering

Ryerson University

In reverse logistics (RL), the returned products are collected and some recovery activities are applied. The objective of this project is to identify the RL components of cellphones in three provinces of Canada. There have been a number of investigations performed in this sector. But in recent years with the technological advancement of cellphones along with the evolution of smart phones, a rapidly growing secondary market has developed and the RL of cellphones has been very complex. In this project, we make the effort to draw a clear picture of the RL framework of cellphones in Canada, highlighting the policies and practices in three provinces: British Columbia in the west coast, Ontario in the middle, and Nova Scotia in the east coast. In doing this, we discuss about the physical, chemical and recoverable components of cellphones as well as the recovery options. We review the literature on cellphone RL, identify some relevance as well as differences comparing with the Canadian context and address some issues pertinent to provincial contexts. We focus on the high paced growth of the cellphone secondary market and the need for more research on the same. Finally, some managerial insights and suggestions on how the cellphone RL can be more efficiently handled are offered. 


\section{Table of Contents}

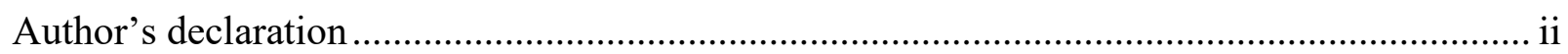

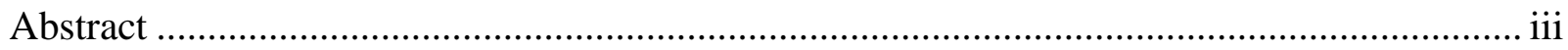

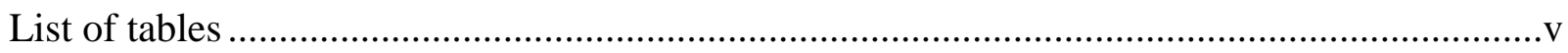

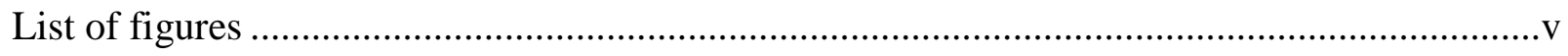

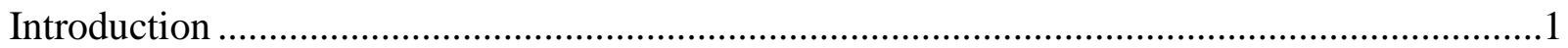

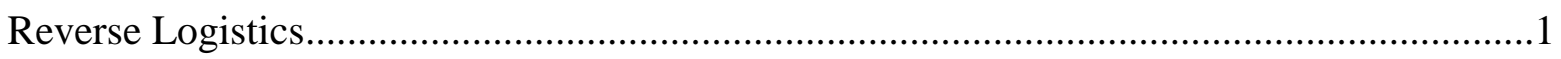

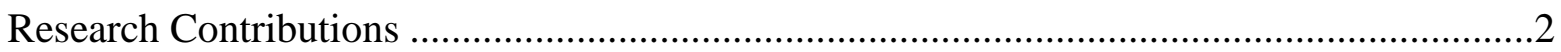

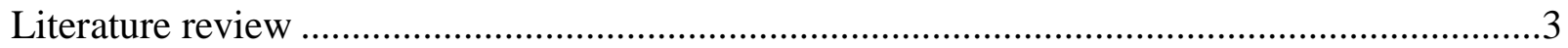

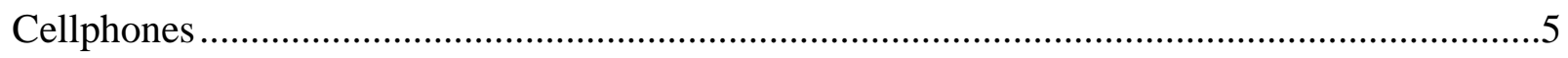

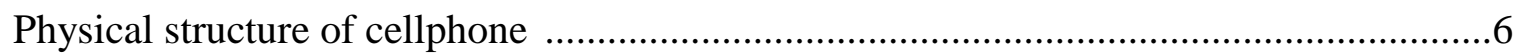

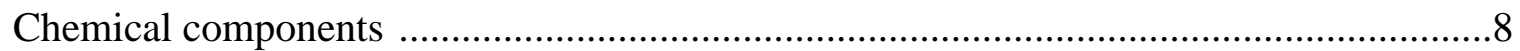

The recoverable components of cellphone …………...................................................9

Characteristics of cellphone from RL perspective …………......................................10

Recovery options of cellphone ...................................................................................

Issues with recovery of cellphone ……………………...............................................11

Reverse supply chain networks of cellphone in Canada .......................................................14

EoL practices of cellphone in Canada …………….................................................14

Statistics on cellphone return in Canada …………….............................................16

National and provincial programs of Cellphone reverse logistics ...........................................17

Provincial policies and procedures .........................................................................17

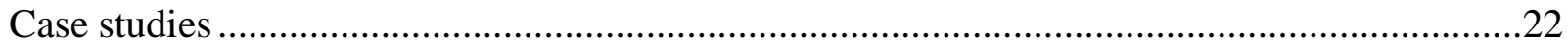

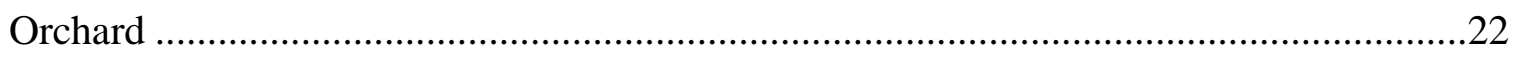

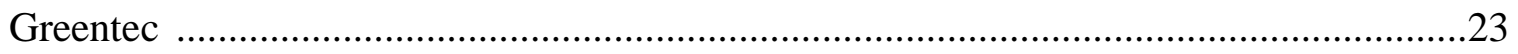

Effects of cannibalization ..........................................................................................24

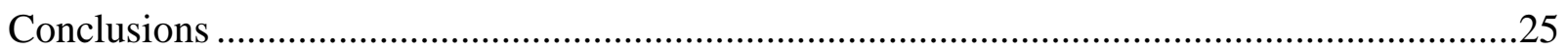

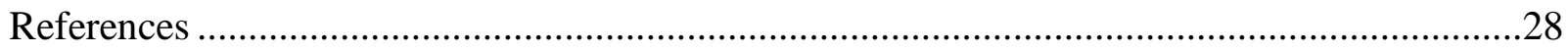




\section{List of tables}

Table1. Disposal of e-Waste by province

\section{List of figures}

Fig. 1. Mobile phone components ............................................................................6

Fig. 2. Cellphone chemical composition .....................................................................

Fig. 3. Recycling rates of smartphone metals .................................................................10

Fig. 4. Average rate of depreciation by make of cellphone ............................................14

Fig. 5. Reverse logistics flow of cellphones in Canada ....................................................16

Fig. 6. Cellphone Recovery at a glance in Canada .............................................................19

Fig. 7. Cellphone Recovery at a glance for BC ..............................................................20

Fig. 8. Cellphone Recovery at a glance for NS ........................................................21

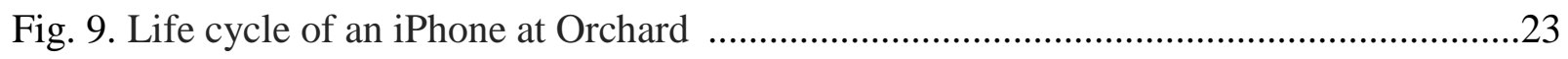




\section{Introduction}

A supply chain, in its classical form (forward supply chain), is a combination of processes to fulfill customers' requests and includes all possible entities like suppliers, manufacturers, transporters, warehouses, retailers, and customers themselves (Chan et al., 2012; Chopra and Meindl, 2015). A supply chain may include forward and reverse supply chains.

\subsection{Reverse logistics}

Our goal in this paper is to conduct research on cellphone reverse logistics. Reverse Logistics can be defined as all activities associated with a product/service after the point of sale, the ultimate goal is to optimize or make more efficient aftermarket activity, thus saving money and environmental resources (Reverse Logistic Association, 2016). There are some literature review papers in this field (e.g. Fleischmann et al., 1997; Akcali and Cetinkaya, 2011; Govindan et al., 2015; Agrawal et al., 2015).

Rogers and Tibben-Lembke (1998) define reverse logistics as: The process of planning, implementing, and controlling the efficient, cost effective flow of raw materials, in-process inventory, finished goods and related information from the point of consumption to the point of origin for the purpose of recapturing value or proper disposal.

\subsection{E-waste and Cellphone}

E-waste refers to all waste that comes from or caused by electronics. Generation of E-waste has been an increasingly important problem in the modern society. It contains materials such as lead, mercury, arsenic and chromium - all known or suspected agents of harm to wildlife and human health. E-waste is a major concern with respect to wireless technology and computers because such items are readily discarded. E-waste represents only $2 \%$ of America's trash in landfills, but it equals $70 \%$ of overall toxic waste (Slade, 2007). It is growing 4 times faster than other waste streams but only $12.5 \%$ of that waste is being recycled (U.S. Environmental Protection Agency, 2012). 20 to 50 MT of E-waste are disposed worldwide every year. Personal information and communication technology (ICT) devices — such as mobile phones, personal computers, and printers - accounted for $7 \%$ of e-waste in 2014, more specifically, 3.0 million tonnes of small ICT equipment which included mobile phones (Baldé, 2015; Guarnieri et al., 2016). 
Now let's consider some facts on the flip side of the above stats. Most of the components of a mobile phone are recyclable: $40 \%$ plastics, $15 \%$ glass and ceramics, $15 \%$ copper and compounds, and so on (Mobile Phone Partnership Initiative, 2008). According to U.S. Environmental Protection Agency (2016), for every 1 million cellphones that are recycled, 35,274 lbs of copper, $772 \mathrm{lbs}$ of silver, $75 \mathrm{lbs}$ of gold, and $33 \mathrm{lbs}$ of palladium can be recovered. A large number of what is labeled as "e-waste" is actually not waste at all, but rather whole electronic equipment or parts that are readily marketable for reuse or can be recycled for materials recovery. Rising demand for e-waste recycling and re-use presents business opportunities and economic benefits that include job creation and local development. Valuable materials such as glass, plastic, aluminum, copper and gold can be salvaged from used electronics. E-waste re-use organizations and recyclers are active in most provinces and will likely continue to expand. In 2000, Ontario was home to four companies in the business of ewaste recycling; by 2004, there were 14 companies. If we add all these facts to the gloomy picture of E-waste, a research study on the reverse logistics management perspective of cellular phones becomes more interesting and worthy.

\subsection{Research contributions}

Based on our knowledge, there are very few research papers about reverse logistics of cellphones particularly in Canada. Considering the geographic positions in the map of Canada, we thought that Nova Scotia (Eastern Canada), Ontario (Mid Canada) and British Columbia (Western Canada) would be a good representation for cellphone reverse logistics in Canada and decided to focus on these three particular provinces. There are not enough scientific papers in the literature focusing on reverse logistics in Ontario, British Colombia, and Nova Scotia. We also noticed that there is a vast unexplored area in cellphone reverse logistics where information is not readily available or quality of information is not good enough to have distinct conclusion. As a result, we feel the urge to conduct some research in order to draw a clearer picture of cellphone reverse logistics in these three provinces. In doing so, we examine the common recovery options such as reusing, repairing, remanufacturing, and recycling of cellphones. We discuss pricing issues related to the returned and remanufactured products in an innovative way. Furthermore, existing Canadian federal and provincial policies on recycling of cellphones are discussed. 
In Section 2, we review some literature related to cellphone reverse logistics and identify gaps. Section 3 discusses the physical and chemical components of cellphones as well as identifies the recoverable parts of a cellphone. In Section 3, we discuss the physical structure, chemical components of cellphones as well as identified the recoverable parts in it. In addition, we highlight the uniqueness of cellphones in reverse logistics standpoint. In Section 4, common End of Life (EoL) practices of cellphones in Canada are presented and complemented by some data and figures. In Section 5, we examine how the reverse logistics process is being handled in three provinces of our context and how they differ between provinces. Section 6 includes case studies on two companies, which have positive impacts on cellphone RL. Greentec is one company which is involved in recycling by dismantling cellphones and Orchard is involved in reselling cellphones. In Section 7, we discuss the effects of cannibalization on cellphones and how it affects the revenue and market shares of existing cellphone manufacturers. In Section 8, we share our observations as we try to identify the barriers and opportunities for reverse logistics of cellphones in Canada, find managerial insights and make useful recommendations about reverse logistics.

\section{Literature review}

The literature review shows that researches have been performed on recovery of cellphones values; values recovered by reuse or values recovered by recycle. Research on cellphones in particular emerged around 19 years ago when they were targeted by European policy makers (Clift, 1997). Five companies formed the ECTEL Environmental Task Group: Alcatel, Ericsson, Motorola, Nokia, and Panasonic, who ran a pilot project over a period of six months in order to provide meaningful data about taking back of small electronic products. Their aims were to:

- Implement a mobile phone collection, redistribution, and recycling infrastructure.

- Actively encourage participation by all parties in the take-back chain including retailers, distributors, municipal waste authorities, and recyclers.

There were a number of publications that were commissioned by ECTEL which included recommendations of end-of-life mobile phone management (Clift and Wright, 2000) or a lifecycle energy model for take-back and recycling mobile phones (McLaren et al., 1999). In group research performed by Geyer (2006), the authors recommended an optimal end-of-life (EoL) management option for cellphones within the United States considering U.S. legislation as well 
as global design trends that affect the economic and environmental outcomes of various management schemes. The authors of the project considered three end-of-life management options: the reuse of phones, reuse of components, and recycling of materials. Results highlighted the importance of having a minimum reuse rate in order to ensure positive economic outcome and made practical recommendations to ensure the sustainability of the EoL cellphones market in the near future. The authors agree that any policy should be re-evaluated regarding both its economic and environmental benefits as the market develops. Geyer and Doctori Blass (2010) examined the economics of cellphone reuse and recycling based on detailed primary data collected from reverse logistics, reuse and recycling operations in 2003 in the UK and in 2006 in the US and showed that while cellphone reuse has a healthy profit margin, handset recycling is currently a by-product of reuse.

More recently, Ponce-Cueto et al. (2011) characterized the reverse logistics system and analysed the challenges for reverse logistics practices with the Spanish mobile phone industry. They identified that causes for the inefficiencies in the system are: very low rate of recovery through "Official" channels, emergence of large secondary market because of the existing value eased by volume and portability of cellphones, which in turn poses the risk of proper EoL disposal and finally, a fragmented logistics system for cellphone recovery. Moreira de Moraesa et al. (2014) assessed two reverse logistic scenarios of cellphones using the technique of life-cycle assessment (LCA). The first scenario reflects the current scenario in Brazil, where batteries are recycled in Brazil, and the other parts of the phones are outsourced to Europe. The second scenario is a proposal of full treatment in Brazil. The authors indicated that the second scenario has a lower potential impact with important reduction of acidification, photochemical oxidation, eutrophication and the use of non-renewable energy as well as add socioeconomic benefits from the sale of materials and the generation of employment and income. Pandian (2015) in the thesis at University of Windsor investigated performance evaluation of a reverse logistics enterprise with an agent-based modelling approach. The authors considered the major entities in the RL network as agents that can act independently with several different agents: collector agent, sorting-cum-reuse agent, remanufacturing agent, recycler agent, supplier agent, and distributor agent. The individual performances of each agent have been measured and recommendations have been given to improve their performances, leading to the enhancement of the total 
performance of the RL enterprise. The solution approach has been applied to a case study involving a cell-phone remanufacturer.

There are some other papers in the literature about cellphones recycling (Ponce-Cueto et al., 2011). In 2004, with increasing focus on life-cycle assessment of mobile phones, Huisman applied his own environmental assessment methodology of mobile phones (Huisman, 2004). Guide and Van Wassenhove (2009) discussed managing product returns for remanufacturing. Guide et al. (2005) published the ReCellular Inc. case, which includes a U.S. remanufacturing case of mobile phones. Franke et al. (2006) developed a simulation model for mobile phone remanufacturing using linear optimization and discrete-event simulation. Dedrick et al. (2011) proposed a novel methodology to analyze three phone models. They provided useful information about mobile phone industry. Velmurugan (2016) discussed environmental and health impacts of mobile phone production. Argenta et al. (2017) analyzed recycling materials and methods related to some part of mobile phone such as LCD screens.

In the literature review, we found that the most of the mentioned articles and journal papers emphasize on the environmental impacts of cellphone recycling as well as some recovery options including remanufacturing. The papers, however, largely overlooked 1) how the speed of technological advancement is affecting cellphone reverse logistics, 2) the role of the rapidly growing secondary market in the reverse logistics framework. In addition, we observed that research performed and papers published or available mostly encompass the time from the beginning of cellphone recycling when the eWaste issue started being addressed and miss out on the rapid technological advancement of cellphone in the most recent years. Furthermore, most of the peer-reviewed journal publications offer mathematical and theoretical models, not real cases. Besides, other than the thesis by Pandian (2015) at University of Windsor, we did not come across any paper that deals with cellphones in Canadian context.

\section{Cellphones}

Two general types of cellphones are currently being used: feature phones and smart phones. Feature phones are phones that provide basic functionality of a cellphone. Other than calling and receiving calls, these basis functions may include internet access, camera, music player etc. They are usually low priced and somewhere in between the basic cellphone and cellphone with advanced functionality like integrated apps, multitasking features etc. Smart phones, on the other 
hand, are cellphones with advanced computing capabilities that run on Mobile Operating Systems (OS). These mobile operating systems (e.g. IOS by Apple, Android by Google etc.) offer advanced Application Programming Interfaces (APIs) to allow third party applications (popularly known as 'App') to run on phones. These applications have better integration with the phone's OS and hardware than typical feature phones (Singh, 2012). Smart phones typically have bigger screens with touch screen options.

\subsection{Physical structure of cellphone}

A cellphone typically has some major components including mother board, screen, camera, housing, and battery (URL:cnoemphone.com/industry/mobile-phone-components).
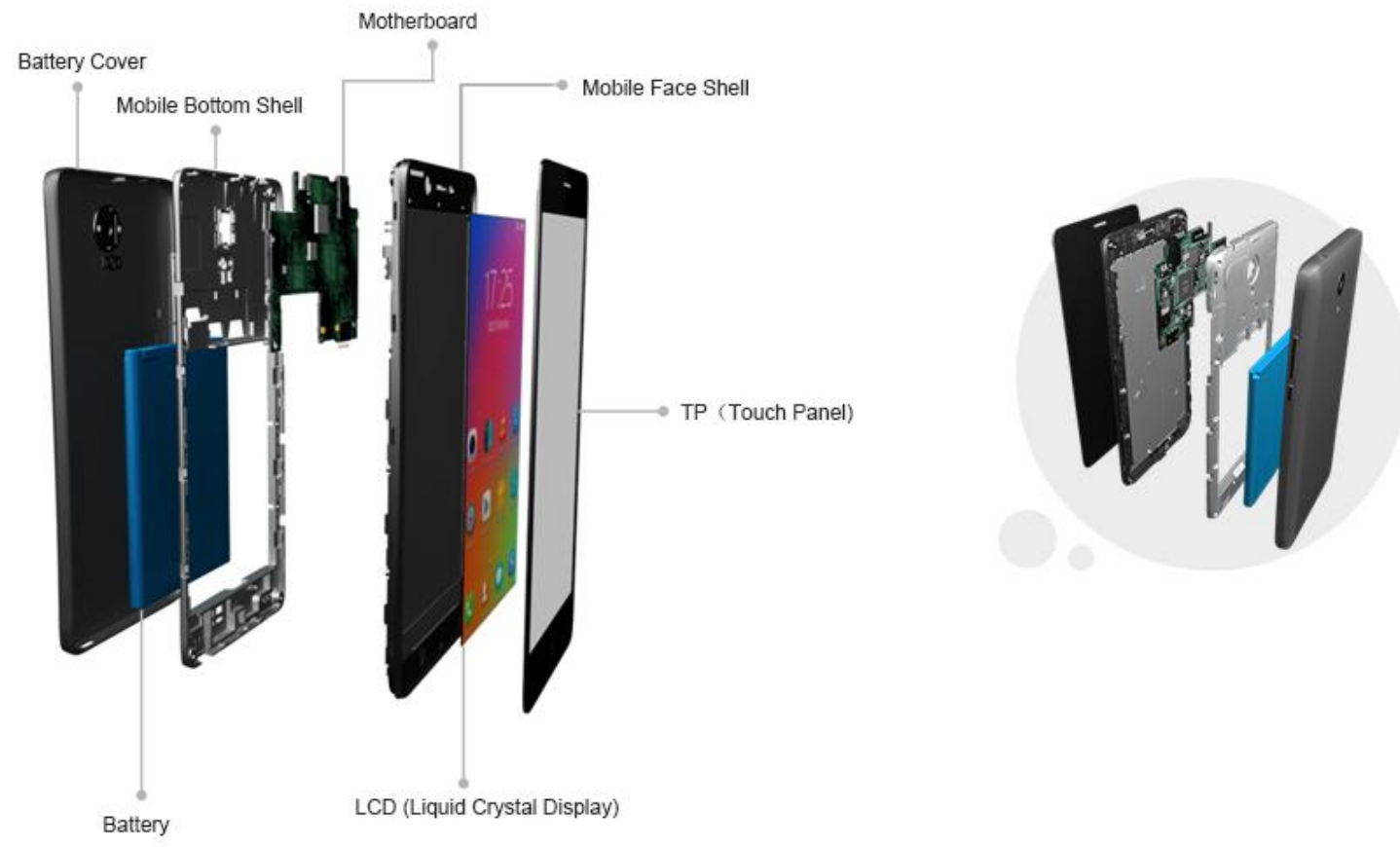

Fig. 1. Adapted from cnoemphone, URL:cnoemphone.com/industry/mobile-phone-components

\subsubsection{Mother board}

The most important part of a cell phone is the motherboard, which holds many important chips, such as process chips, memory chips, Input/Output (I/O) chips, and the expansion slots for connecting peripherals. Some chips are soldered onto the motherboard (permanent), and some are removable. Thus, they can be upgraded. Components of a mother board typically are:

- Ram (Random Access Memory) 
- $\quad$ Rom (Read Only Memory)

- CPU (Central Processing Unit)

- GPU (Graphic Processing Unit)

- GPS (Global Positioning System)

- Wi-Fi (Wireless Local Area Network)

- Bluetooth

- GPRS (General Packet Radio Server)

- Baseband

- Antenna

\subsubsection{Screen}

Screen of a mobile phone or a smartphone is one of the key features, users are concerned with when buying a new mobile device. Display screen is the main hardware that user can interact with the software and has various capabilities. Display screen has been evolved and today humans reached the milestone of making flexible screens. There are a lot of display types used in mobile phones. The following parts are components of screen in a cellphone:

- Protector Glass

- Touch Panel

- LCD (Liquid Crystal Display)

The above three parts either need a frame lamination or a full lamination in order to make the screen.

\subsubsection{Camera}

Cameras are integral parts of cellphones now a days and the technological advancement of using cellphone cameras poses the risk of cannibalization of some points and shoot cameras. Some phones are able to take still picture or video by using the camera. The pictures and/or video then can be sent wirelessly, or sometimes associated with phone book entries and used for picture ID on incoming calls. Quality of camera is affected by many factors including resolution and lens focus type (fixed or auto focus).

Camera consists of the following parts:

- Camera lens 
- Color filter

- Image sensor

- Circuit baseplate

Some of the aspects of camera are pixels, aperture, focusing, VCM (Voice Call Monitoring).

\subsubsection{Housing}

As the name indicates, housing is outer cover of the cellphone that covers everything inside. The manufactures make great effort to make the housing attractive as it makes the first impression about the device. Durability is also very important factor and different kinds of material are used. Housing consists of three components:

1. Face shell: Face shell is the basic structure of a cell phone. Phone's camera, handset, buttons and infrared sensor need to be embedded in the face shell for fixing. Polycarbonate is a typical material used widely in mobile phone shell.

2. Bottom shell: Bottom shell is the basic structure of a cell phone as the mobile face shell. Bottom shell inlays face shell for fixing the outer components of mobile phone.

3. Battery Cover: It is an important part of the housing and a part of the appearance. Different materials are used to make the back cover. They can be $2.5 \mathrm{D}$ non-removable cover, metal non-removable cover, plastic removable cover, etc.

\subsubsection{Battery}

Cellphone obtains power from rechargeable battery. A is an electrochemical cell that can be charged to provide electrical charge when needed. Cellphones need battery to start working for any operation. A popular early mobile phone battery was the nickel metal-hydride (NiMH) type. Some manufacturers used lithium ion batteries and then some use Lithium polymer as opposed to Lithium ion for ease of use and shape.

\subsection{Chemical components}

Chemical components play key roles in cellphone recycling because of two reasons. Firstly, there are chemicals that have long term health hazard. Secondly, many of the chemicals are valuable (e.g. gold, silver). In addition, cellphone uses rare earth elements (e.g. Neodymium, Terbium, and Erbium). Fig. 2 illustrates the percentage wise chemical compositions of a cellphone. 


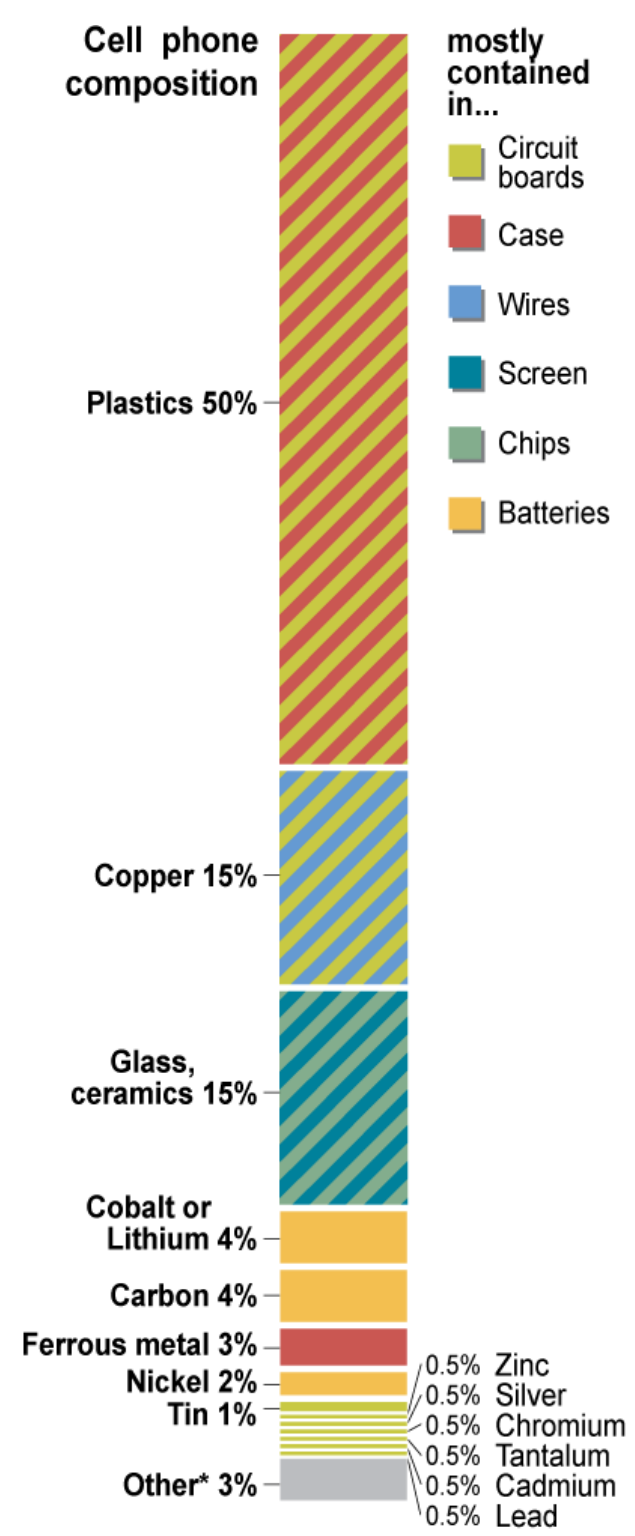

*among them, less than $0.1 \%$ of antimony, gold and berrylium

Sources: Basel Convention, 2006; Lindholm (Nokia report), 2003.

Fig. 2. Adapted from GRID Arendal, Credit: Cécile Marin, URL:

http://www.grida.no/graphicslib/detail/cell-phone-composition_1057

\subsection{The recoverable components of cellphones}

There are 10 to 12 major physical components in a standard cellphone and the top candidates for remanufacturing are the camera, display, and potentially the battery and charger. They are among the most valuable parts within a phone, are comparatively easy to disassemble, and could be used in the production of new devices or in aftermarkets (Ellen Macarthur Foundation Report, 2012). Typical cellphone consists of 500-1000 components most of which are made of large variety of 
materials and substances (Life Cycle Environmental Issues of Mobile Phones, 2005, Nokia Corporation). There are over 30 metals in a cellphone including valuable materials like gold, silver, and rare earth metals. Half of these metals have functional recycling rate of $50 \%$. Between $20 \%$ to $35 \%$ of the material content of a cellphone is lost when the phone is shredded and melted down for recycling. Fig. 3 shows the periodic table with the recyclability of the metals used in a cellphone.

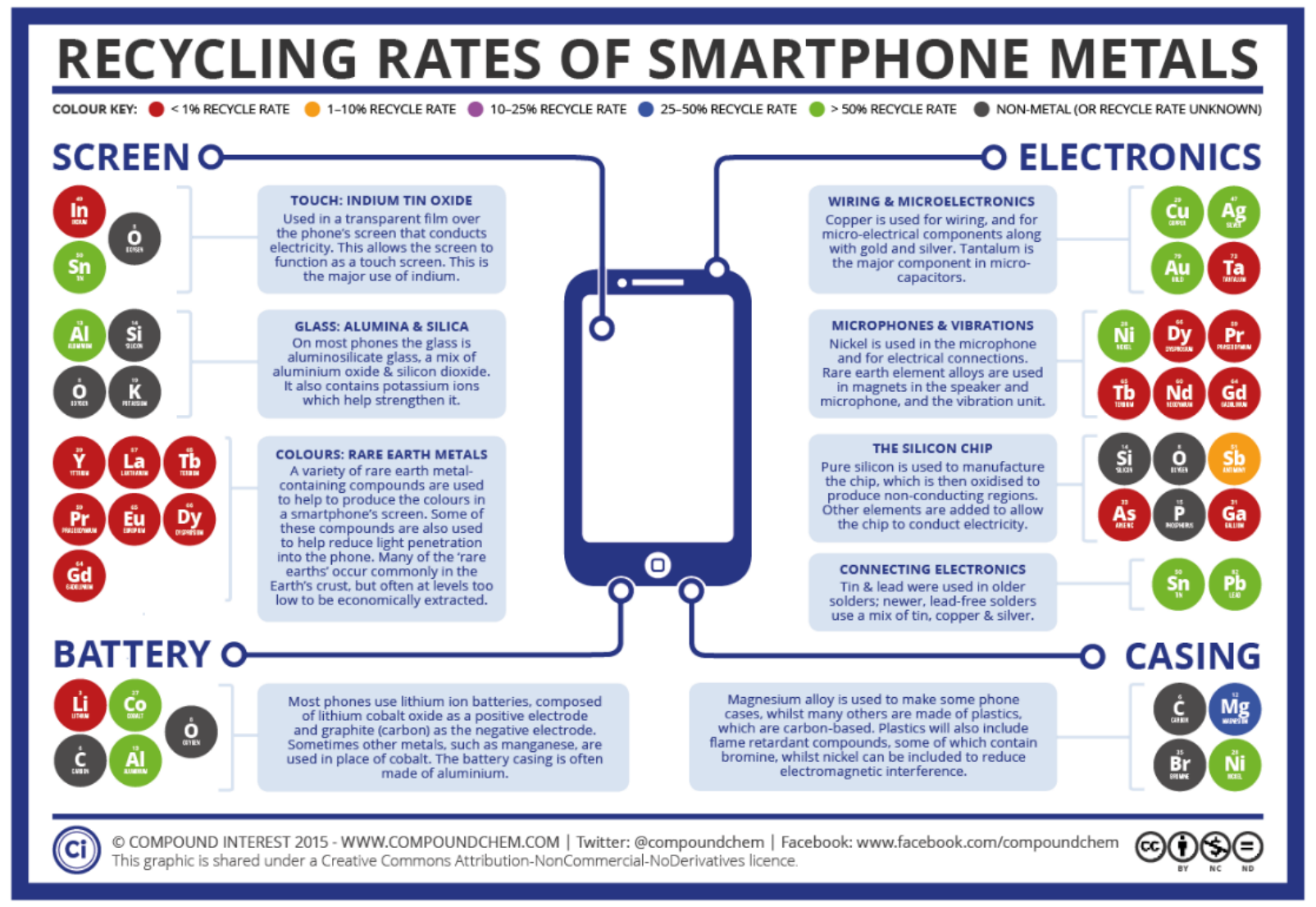

Fig. 3. Elements used in cellphone. Source: URL: http://www.compoundchem.com/2015/09/15/recycling-phone-elements/

\subsection{Characteristics of cellphone from RL perspective}

a. Light weight (approximately 110 grams to 185 grams) which make them portable.

b. Short life span (usually $18-24$ months): The demands for new items compounded by rapidly changing technology allow the manufacturers to bring newer models resulting in faster recycling/refurbishing needs. 
c. Occupy small space: Unlike refrigerators or televisions, one person can own multiple cellphones at the same time.

d. Ease of shipment because of the portability: Making it easily sellable in local secondary market through online marketplaces like kijiji, craigslist, ebay, etc.

e. Owner does not usually throw away the old cellphone.

f. Have unusual resell/residual value: Unlike other eWaste materials, cellphones have better resell as well as recycling value.

g. Returning is free.

h. Third-party companies collect cellphones for profit.

\subsection{Recovery options of cellphones}

Common recovery options for a returned product are reusing, repairing, reconditioning, remanufacturing/refurbishing, recycling, and parts harvesting (Ilgin and Gupta, 2012). The six operations can be termed as 5R1P.

Reusing: A returned cellphone can be reused as it is, if it is in working condition. It may need simple cleaning and repackaging. It may include the products that are returned within the valid return period or the products that are sold online at websites like kijiji.

Repairing: Repair involves repairing/replacing a specific faulty part(s). The rest of the product needs minimal checking.

Reconditioning: Sometime a product may need some cleaning/surface polishing and usually only at the surface level.

Remanufacturing: Remanufacturing is defined as "the process of restoring a non-functional, discarded, or traded-in product to like-new condition" (Lund, 2012). It is the process of giving a cellphone a total new life after EoL. It is the most important recovery option in terms of the time and process.

Recycling: Recycling is extracting values from cellphone at the material level. It involves the process of material reconstruction by melting material like plastic and glass and manufacturing new products.

\subsection{Issues with recovery of cellphones}

We can divide recovery of cellphones into collection (return) of cellphones, and recovery of cellphones from returned devices. From Recycle My Cell statistics (Fig. 5), we can see that the 
rate of recovery is not very encouraging for both cases. In this section, we review some issues related to the recovery of cellphones.

\subsubsection{Lack of awareness about cellphone recycling}

A large number of consumers are not fully aware of the recycling procedures, advantages, incentives, and programs. Although the number of people is increasing with various forms of education, in many instances, they do not even know if the cellphones are recyclable.

\subsubsection{Lack of efficiency of RL}

An effective and efficient RL procedure for cellphones is essential to recover greater number of cellphones which are going into the landfill or being stored at home instead.

\subsubsection{Cost}

It is difficult to compensate the cost of collection, inspection, testing, refurbishment, and redistribution with the profit made from selling remanufactured products or recycled materials. That is why remanufacturing baked by legal regulations works better. The lower the take back cost compared to the residual values of cellphones, the higher the chances of voluntary take back.

\subsubsection{Lack of incentive}

There is not enough incentive for the consumers to return cellphones. In many cases, the incentive offered is so small that they don't feel the urge to return or recycle the cellphones. Greater monetary value for cellphone returning, more education on the importance of recycling could be among the incentives that can change the mindset of customers.

\subsubsection{Price of resalable cellphones}

There is no standard or set price for used cellphones that can be resold, and consumers often are confused about buying or selling used cellphones. For example, an old cellphone without touchscreen capabilities can be of zero resale value, where as an iPhone 4 or iPhone 5 can have significant value. 


\subsubsection{Role of technology}

Technology plays an important role in determining the residual value of cellphones. Cellphones in recent time become outdated very fast as a result of the fast technological advancement. Therefore, cellphones lose their appeal as well as the price quickly.

\subsubsection{Role of contracts with carriers}

The contracts offered by the carriers also play an important role in recycling of mobiles phones. Carriers usually encourage trade in, and recycling programs. They usually offer hardware upgrade options which allow existing customers to have newer cellphone models without any upfront cost. These options have two implications:

1. The older cellphones become obsolete, many times well before the end of their useful life.

2. Being locked to the carriers' networks, in many occasions they are simply stored or kept away without being used.

\subsubsection{Brand of cellphone}

Brand of cellphones is a very important factor in determining residual value which consequently affects the reverse logistics. According to a new study by used gadget sales site Decluttr, used iPhone hold their resale value better than other leading smartphones like Samsung, LG, Sony, etc. Fig. 4 gives a comparison of depreciation of some leading brand cellphones. 


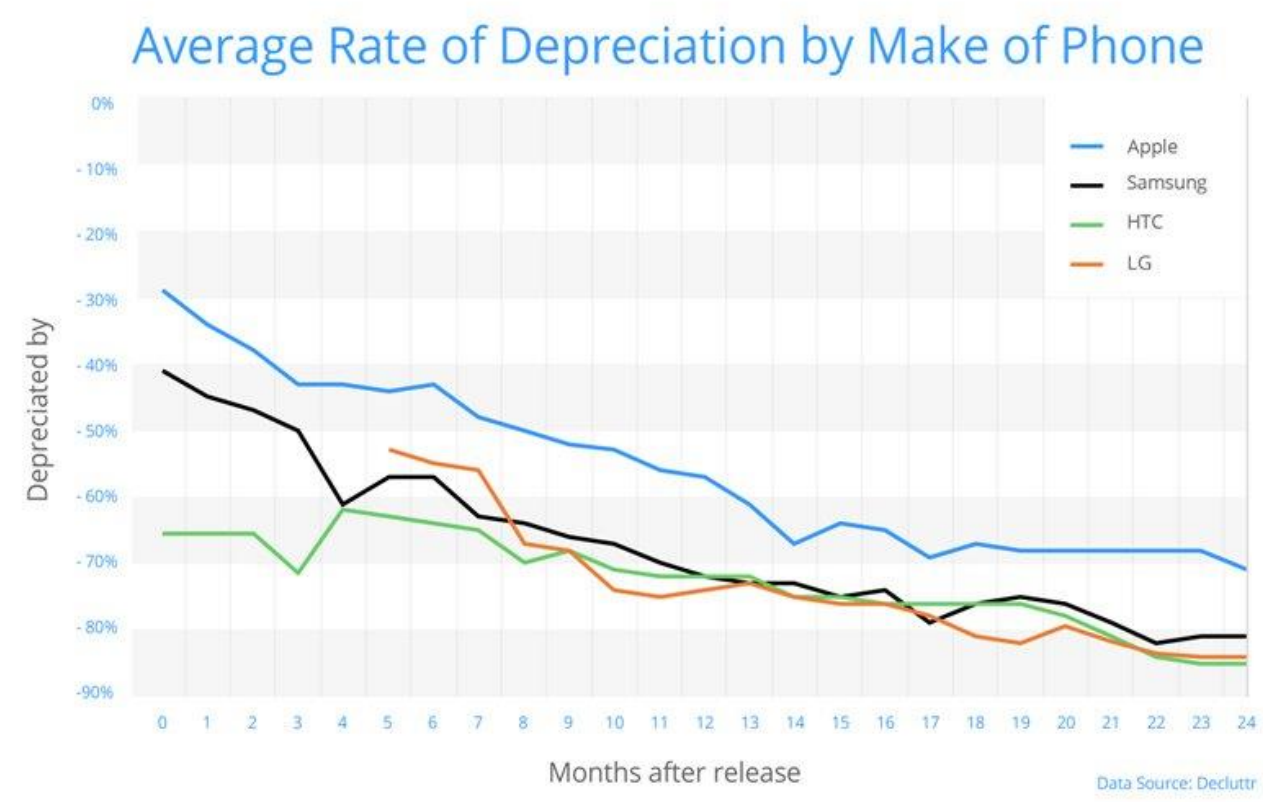

Fig. 4. Adapted from URL: http://www.decluttr.com/blog/2017/04/05/how-quickly-does-yourphone-depreciate-in-value/

\section{Reverse supply chain networks of cellphones in Canada}

The elements involve in forward and reverse logistics of cellphone can be broadly divided into the following three categories:
A. Users: Users are the consumers or buyers that use cellphones. In reverse logistics, the flow of cellphone starts from users.
B. Carriers: They are the distributors of cellphones. They are the wireless service providers that connect cellphones to wireless networks. In many cases, they own the network.
C. Manufacturers: Manufacturers are the ones that design and manufacture the cellphones.

\subsection{EoL practices of cellphones in Canada}

Currently, old cellphones are being disposed in four different ways: keep, reuse, recycle, garbage (landfill). 
4.1.1. Keep (Store it away): Users either just store them away or they still use them for different purposes. According to Recycle My Cell report (Fig. 6), 43\% of user has reported storing their last device.

4.1.2. Reuse: Reusing happens when a cellphone is repurposed, or reused as phones, or resold. Cellphones can be used for calling emergency services (e.g. 911). Elderly persons or victims of domestic violence may make such use. They are used sometimes as toys or alarm, or for listening to music. A big portion of cellphones are resold in secondary market like ebay or kijiji. Some people prefer to donate to charity where they are further reused. Some of the cellphones are gifted to family or friends for reuse. A number of cellphones that are lost or stolen are reused in many cases.

4.1.3. Recycle: This is the increasingly popular method of disposing cellphones. There are a number of programs available for recycling. For example:

1. Trade-in or take-back programs (e.g. Best Buy, Bell, Apple).

2. Recycling programs (e.g. recycle my cell).

3. Other methods of collection (e.g. recycling for profit businesses like Orchard.ca). The cellphones collected from these programs are processed in the following ways:

1. Refurbish: The cellphones collected are reconditioned, tested for functionality and defect, and sold to customers.

2. Dismantle and parts recycled: Cellphones are dismantled and parts are reused in rebuilding.

3. Smelter: Get broken down and sold for parts or passed on to a smelter (material reconstruction). Gold, copper, iron, silver, zinc, nickel, platinum, tin used in the circuit boards and soldering. In one metric ton of old cellphones without batteries (about 8,800 individual phones), there's an estimated 308 pounds of copper, 7 pounds of silver, and half a pound of gold (Quraishi, 2010)

4.1.4. eWaste: Cellphone going to landfill has significantly dropped in recent years. About $4 \%$ of the cellphones in 2015 were trashed (Fig 6). A more recent (2016) statistics from Recycle My Cell website (URL: http://www.recyclemycell.ca/facts-and-figures/) shows an even more drop in 
cellphone going to landfill (2\%). We have analysed the EoL practices in Canada from the available sources mentioned in this article, to illustrate our findings in fig. 5 with a flow diagram.

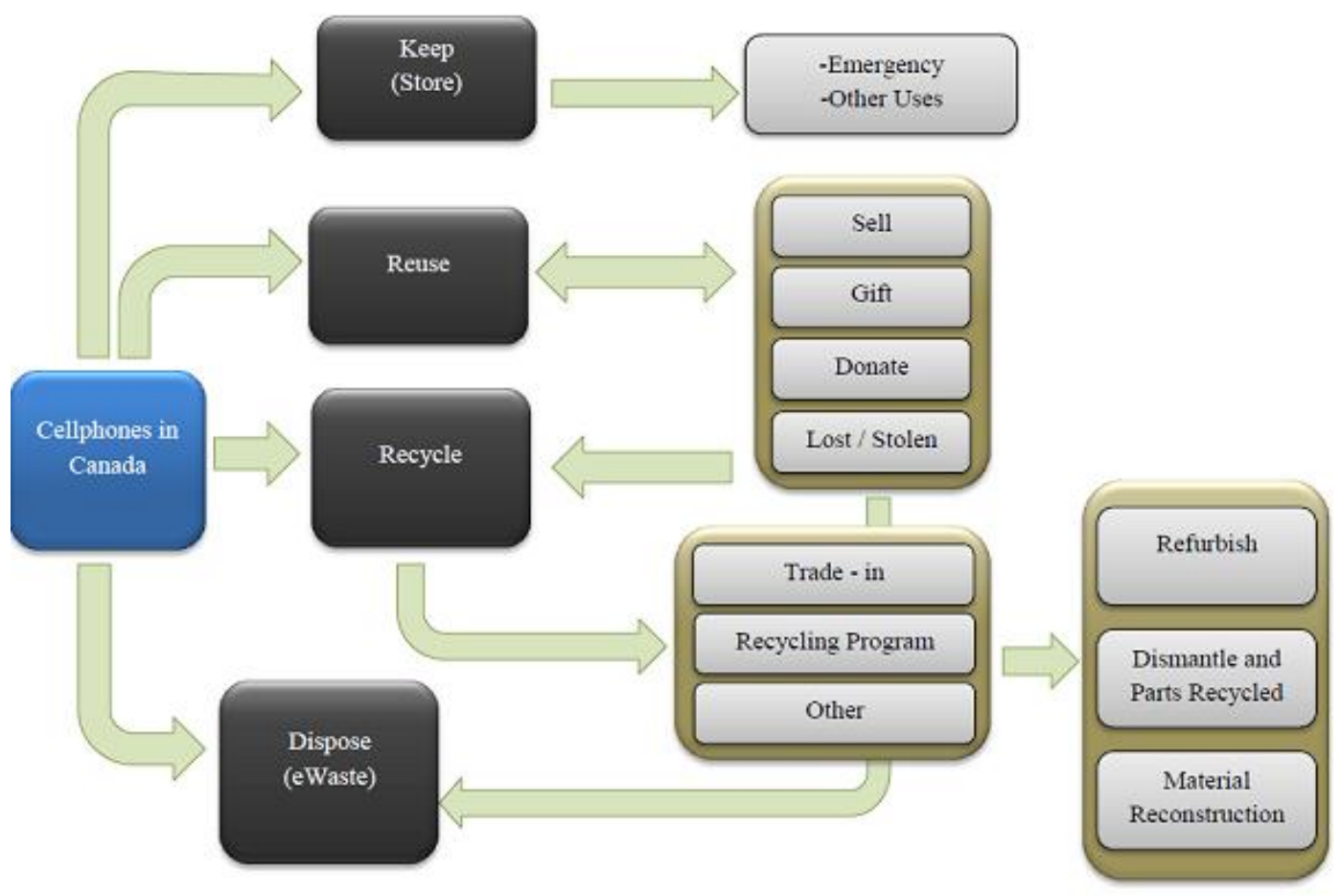

Fig. 5. Reverse logistics flow of cellphones in Canada

\subsection{Statistics on cellphone return in Canada}

There is no concrete data available on cellphone returns. Table 1 shows the cellphone return data in percentage in Canada including the three provinces in the context. 
Table1

Disposal of e-Waste by province. Adapted from Statistics Canada (URL:

http://www.statcan.gc.ca/pub/11-526-x/2013001/t018-eng.htm)

\begin{tabular}{|c|c|c|c|c|c|c|c|c|}
\hline \multirow{2}{*}{\multicolumn{2}{|c|}{$\begin{array}{l}\text { Had dead or unwanted } \\
\text { cellular phones to dispose } \\
\text { of }\end{array}$}} & \multicolumn{7}{|c|}{ Had dead or unwanted cellular phones to dispose of $(\%)$} \\
\hline & & $\begin{array}{l}\text { Put } \\
\text { them in } \\
\text { the } \\
\text { garbage }\end{array}$ & $\begin{array}{l}\text { Took or } \\
\text { sent them } \\
\text { to a depot } \\
\text { or drop- } \\
\text { off centre }\end{array}$ & $\begin{array}{l}\text { Returned } \\
\text { them to a } \\
\text { supplier } \\
\quad \text { or } \\
\text { retailer }\end{array}$ & $\begin{array}{l}\text { Donated } \\
\text { or gave } \\
\text { them } \\
\text { away }\end{array}$ & $\begin{array}{c}\text { Repaired } \\
\text { or sold } \\
\text { them }\end{array}$ & $\begin{array}{l}\text { Still } \\
\text { had } \\
\text { them }\end{array}$ & Other \\
\hline Canada & 18 & $5 \mathrm{E}$ & 25 & 19 & 8 & $\mathrm{~F}$ & 44 & $2 \mathrm{E}$ \\
\hline Nova Scotia & 18 & $\mathrm{~F}$ & $34 \mathrm{E}$ & $30 \mathrm{E}$ & $\mathrm{F}$ & $\mathrm{F}$ & $25 \mathrm{E}$ & $\mathrm{F}$ \\
\hline Ontario & 17 & $\mathrm{~F}$ & 26 & 18 & 10 & $\mathrm{~F}$ & 41 & $\mathrm{~F}$ \\
\hline British Columbia & 20 & $\mathrm{~F}$ & 19 & $17 \mathrm{E}$ & $15 \mathrm{E}$ & $\mathrm{F}$ & 46 & $\mathrm{~F}$ \\
\hline
\end{tabular}

F: Too unreliable to be published

E: Use with caution

\section{National and provincial programs of Cellphone reverse logistics}

We look into three provinces that are geographically suitable to represent Canada. We consider that British Columbia in the west coast, Nova Scotia in the east coast, and Ontario representing the middle make good representation of the whole country. For two of these three provinces Recycle My Cell is used as a sole body for all kinds of cellphone recycling programs. For some provinces like Ontario, there are many profit and non-profit organizations that are involved in recycling of cellpones.

\subsection{Provincial policies and procedures}

Extended Producer Responsibility (EPR) is a type of national initiative which targets all kinds of mobile/wireless devices. Recycle My Cell is a free national industry-led recycling program for mobile devices under this initiative. This is mandatory in British Columbia, Manitoba, Nova Scotia, and Prince Edward Island, but voluntary in other provinces of Canada. The program is run by the Canadian Wireless Telecommunications Association (CWTA) in conjunction with cellphone carriers, handset manufacturers, and certified processors. Consumers and the general 
public can return mobile devices and accessories to any of the drop-off collection sites, which include retail stores, or they can mail them using a pre-paid mailing label.

Recycle My Cell has received regulatory approval from the province of Nova Scotia (October 2008), and British Columbia (November 2009). Recycle My Cell has also been formally recognized as the official cellular phone stewardship program within the provinces of Prince Edward Island and New Brunswick (March 2009), Manitoba (April 2009), Newfoundland and Labrador (July 2009), Saskatchewan (November 2009), and Alberta (June 2011). In all remaining provinces, it operates on a voluntary basis (Environment and Climate Change Canada, 2016).

\subsubsection{Cellphone recycling in Ontario}

In Ontario, the recycling of cellphones is carried out under Ontario Electronic Stewardship (OES) through 4 channels:

1. OES Service Provider

2. Collection events

3. Retailer

4. Municipal

In addition, there is voluntary participation to the national cellphone recycling program Recycle My Cell. Carriers like Bell, Fido, Rogers, and manufacturers like Blackberry, Sony, LG, Samsung, Microsoft have participating programs with Recycle My Cell. Fig. 5 shows the cellphone scenario of all provinces at a glance. They now have over 4,000 drop off locations across Canada, and have collected over 6.4 million old cellphones. 


\section{RECYCLE MY CELL 2015}

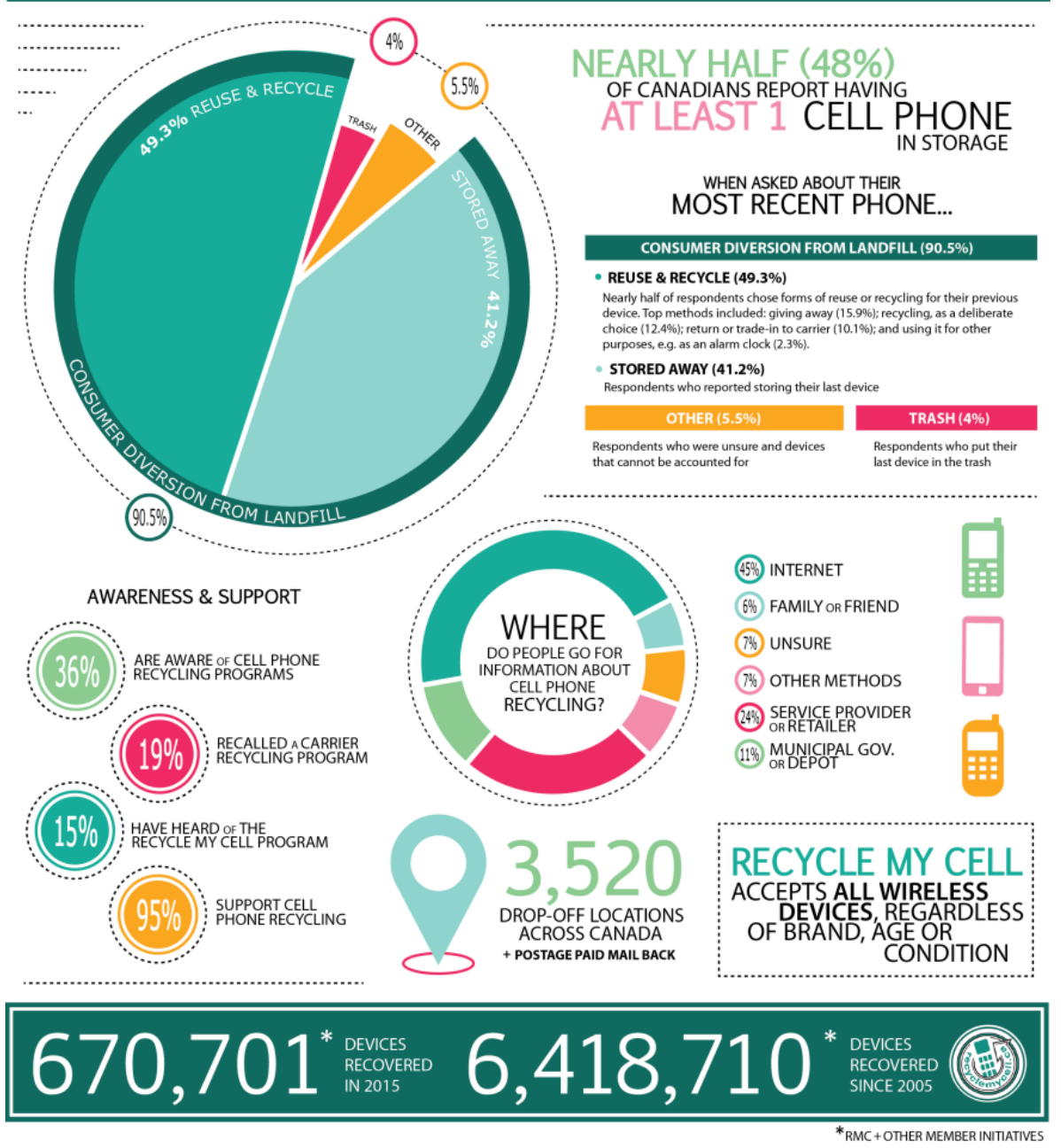

Fig. 6. Cellphone Recovery at a glance in Canada. Source: http://www.recyclemycell.ca/factsand-figures/

\subsubsection{Cellphone recycling in British Columbia}

Recycling Council of British Columbia (RCBC) is the body responsible for product stewardship in BC. Until Recycle My Cell came into operations, Call2Recycle ${ }^{\circledR}$ was the only free battery and cell phone collection program in North America that collected batteries and cell phones in BC. The collected products are shipped for free to a consolidation facility where the batteries and cell phones are separated by type and then forwarded for recycling. The recycling facility processes the reusable metals from the batteries, and prepares them for use in new products such as batteries and stainless steel. Cell phones are refurbished and resold when possible. A portion of 
the proceeds received from the resale of phones benefits Kids Help Phone. None of the reclaimed materials from the battery and cell phone recycling process are sent to landfills (domestic or abroad).

Recycle My Cell has received regulatory approval from the province of British Columbia (2009) and acting as the official cellular phone stewardship program of BC. Fig. 6 gives a glance of cellphone recycling in $\mathrm{BC}$. There are a number of programs and websites related to electronic recycling, but they all drive traffic to Recycle My Cell for mobile phone recycling.

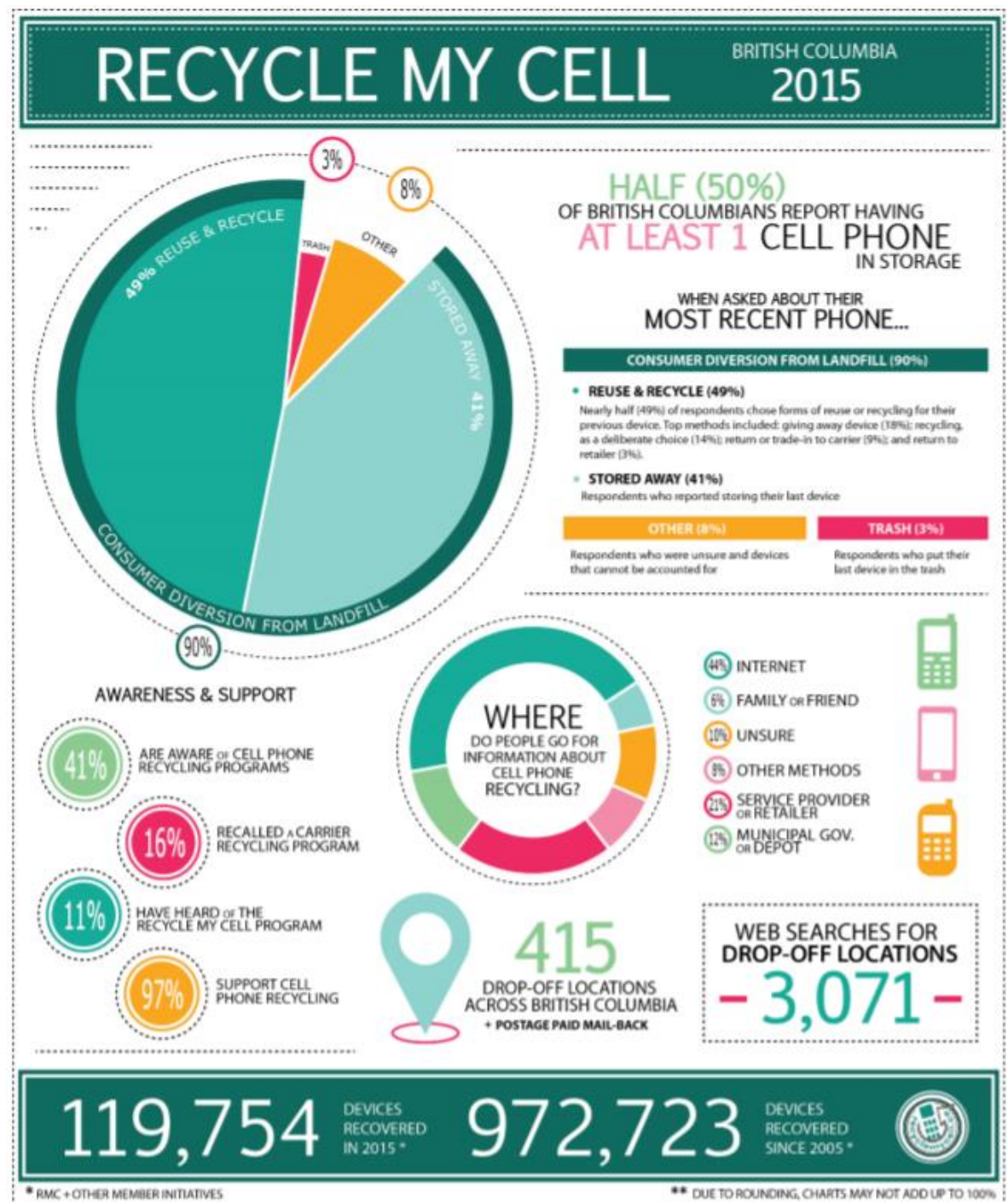

Fig. 7. Cellphone Recovery at a glance for BC, Report 2015 (BC). Source:

https://www.cwta.ca/wp-content/uploads/2016/09/Recycle-My-Cell-2015-Annual-Report-for-

British-Columbia_For-Submission.pdf 


\subsubsection{Cellphone recycling in Nova Scotia}

Like British Columbia, Nova Scotia cellphone reverse logistics program was initially managed by Call2Recycle ${ }^{\circledR}$. But the national recycling program Recycle My Cell was formally recognized as the official cellphone stewardship program in 2009 and cellphone from all kinds of electronic wastes are diverted to Recycle My Cell. In addition, some organizations like divertNS (non-profit) works in collaboration with the official recycling organizations. They work under the department of Nova Scotia Environmental Waste Resource Management. Fig. 7 illustrates the performance of Nova Scotia mobile phone recycling in 2015.

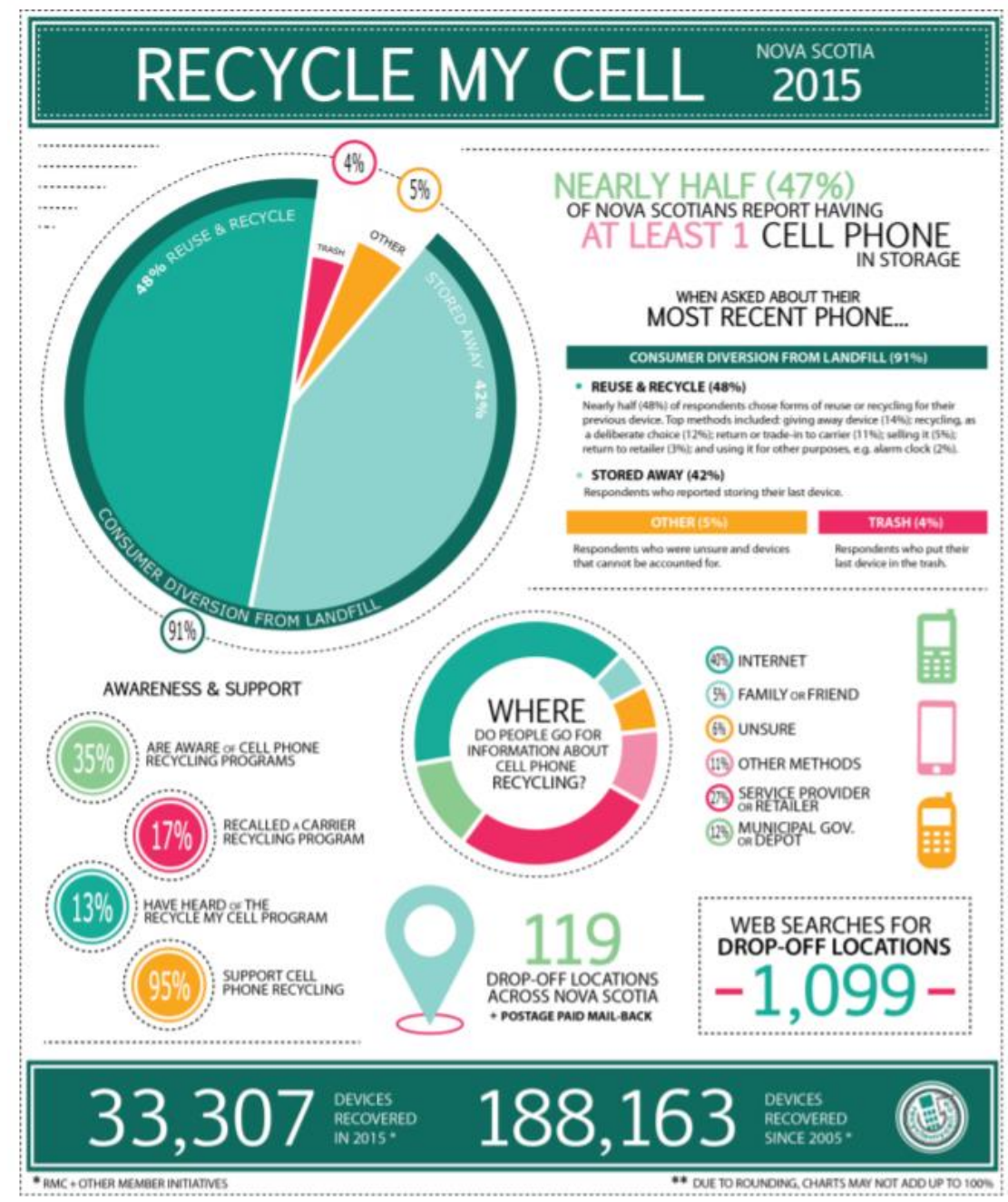

Fig. 8. Cellphone Recovery at a glance for NS, Annual Report 2015 (NS). Source:

https://www.cwta.ca/wp-content/uploads/2016/07/Recycle-My-Cell-2015-Annual-Report-for-

Nova-Scotia_For-Submission.pdf 


\section{Case studies}

Case studies are helpful to analyze problems (Voss et al., 2002). There are a number of companies that make important contributions in reverse logistics scenario in Canada. Some of them are involved in reselling cellphones and some others are responsible for recycling used cellphones. Although there are quite a few companies in both categories, we chose one company from each category because of their novel approach. Orchard is one such company which is involved in reselling of cellphones and Greentec is one that is involved in recycling cellphones by breaking down into parts and reusing in different ways.

\subsection{Orchard Labs Inc.}

Orchard is a Toronto based e-commerce company that buys and sells used smartphones across North America. It was a start-up company that started its business by building an iPhone app that runs thorough diagnostics test of the used device and provides a detailed report, including the device's value based on real-time market demand (Lindzon, 2014). Orchard originally built its mobile app with the option to generate a free listing for sellers to share on social media and other online marketplace like eBay or craigslist. Over the course of series of soft launches, this option was dropped in favour of Orchard exclusively brokering sales on behalf of the iPhone's seller. IPhones were sold on a consignment basis, charging a smaller selling fee for the longer seller waits before the iPhone sells. In May 2015, Orchard expanded into the US market by establishing a physical location in San Francisco (Bonifacic, 2015). In 2015, Orchard launched a partnership with Public Mobile to supply the Canadian wireless carrier's customers with refurbished smartphones. Fig. 9 Illustrates how used cellphones are collected and resold by Orchard. 


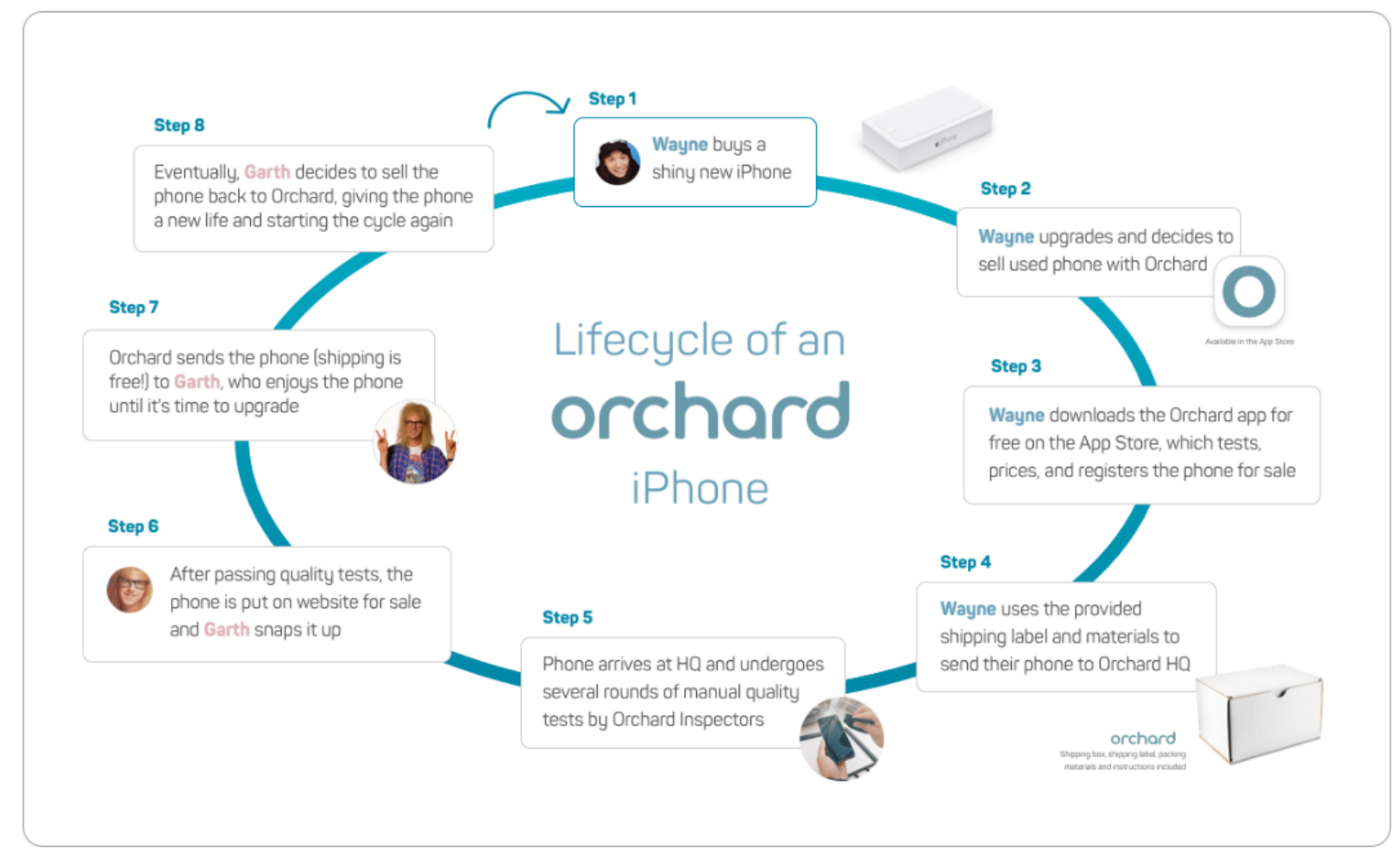

Fig. 9. Life cycle of an iPhone at Orchard. Source: https://www.getorchard.com/how-it-works/

In 2013 Telus acquired Public Mobile and Orchard was relaunched as a cheaper alternative to wireless carrier brands owned by Telus. Part of this transition included store closures and discontinuation of mobile sale under the Public Mobile brand. Instead, Public Mobile partnered with Orchard to supply its customers with carrier locked and unlocked smartphones. Orchard's smartphone lineup has now expanded to Apple, Samsung, HTC, and BlackBerry devices.

Orchard has used innovation to reduce the hassle involved in the selling process of used cellphones. They offer a profitable business model in used cellphone market and at the same time making positive contribution in the RL process of Canadian cellphones.

\subsection{Greentec Inc.}

Greentec is an approved processor with Ontario Electronic Stewardship Program for processing Waste Electrical and Electronic Equipment and is a verified by EPRA (RQP) to conform to the Canadian Electronics Recycling Standards. It is now known as a world leader in recycling electronics. Cellphones collected from Recycle My Cell program is processed by Greentec. It has a 150,000 sq. ft. facility in Cambridge, Ontario that serves North America. It is equipped with 
what is called "electronic waste mining" that separates an electronic device into its base components (metal, glass, plastics, etc.) which are then safely put back into manufacturing process.

All products that come into Greentec's recycling facility undergo a qualifying process to determine if they are suitable for recycling, reuse, or refurbishment. Reuse is considered more viable and less resource intensive solution. The products are carefully dismantled and separated into commodity streams including metal, glass, and plastics. Proper dismantling is vital in order to make sure that the hazardous components like batteries, mercury, and lead do not enter landfill. Valuable components including steel, aluminum, copper, glass, and plastics are shredded and processed as raw materials for future production. Clean materials are reutilized around the world in the production of new goods like bottle, automotive parts, pipes, house sidings, new electronics, kitchen countertops, and carpets.

Greentec has invested considerable resources for improving the quality of recycling with a zero landfill policy and becoming an industry leader in recovery and recycling of electronic wastes including cellphones. It is an example of how cellphones as well as other electronics can be recycled efficiently and responsibly without adding to landfill and at the same time, running as a profitable business.

\section{Effects of cannibalization}

The concept of cannibalization happens in the pricing strategy stage that refers to the reduction in sales volume or revenue (as well as market share) as a result of the introduction of a new product or service (Yeoman, 2012). A company that adopts such a strategy is effectively competing against itself. There are some reasons for a company adapting this strategy. The company may want to increase its market share by gambling that introducing the new product will harm other competitors more than the company itself. Or, the company may believe that the new product will sell better than the first, or will sell to a different sort of buyer. Another reason is the company may want its products to reach customers segments. This is a frequently used strategy by most cellphone companies like Apple or Samsung. For example, when Apple introduced the iPad, it took sales away from the original Macintosh, but ultimately led to an expanded market for consumer computing hardware. In the circumstances that newer iPhone models are introduced, the cannibalization may happen related to the new products (iPhone 7), and the traditional products (iPhones 6). In this case, there is a competition between 
the demand of iPhone 7 and iPhone 6 as long as they are substitutable for the customers. In other words, more sale of iPhone 7 can lead to decrease in sale of iPhone 6.

Another example of cannibalization is its effect on the sale of digital camera (Taylor, 2014). The Camera \& Imaging Products Association reported a 36 percent sales drop in digital camera sales over year in 2013 which can be attributed to the increase in sales of smartphone over the same period that was 38 percent up according to market research firm IDC reports. In addition, cannibalization may seem relevant to our research from an OEM perspective, as the resale market is to a certain extent threat to sales of new cellphones. It will be interesting to develop some quantitative models to examine the effects of cellphone cannibalization.

\section{Conclusions}

In this project, we reviewed different important aspects of cellphone and its reverse supply chain components. We examined the Canadian cellphone recycling and reverse logistics (RL) system with focus on three provinces, namely, British Columbia to represent Western Canada, Ontario to represent mid-Canada and Nova Scotia to represent Eastern Canada. We noticed that provinces that we did not focused on follow similar cellphone recycling programs, and believe that although our focus was restricted to the said three provinces, this research will apply to other provinces of Canada.

Our aim was to create an outline of current situation in Canadian used cellphone market to give readers some understanding and a tool for comparison and further research. We discussed the importance of cellphone RL as well as the differences between cellphones and other electronics from a RL aspect. We observed some barriers in the recovery of cellphones consequently affecting the RL flow. In addition, we examined the EoL practice of cellphones in Canada as well as the federal and provincial policies.

The RL of cellphone is largely affected by collection processes and sources of returned phones. From the statistics and other observations, it is evident that the collection rate is not significant compared to the expectation. This low rate may be attributed to a number of reasons.

We feel that RL process in Canada suffers from lack of incentive or motivation for recycling or reusing used cellphones. Businesses are often guided by money making opportunity and lacks in social responsibility because there is less profit involved in selling refurbished products. The investment for a vendor to sell used cellphones instead of new ones is not feasible. For a 
consumer, incentive is for returning a cellphone is quite low and social responsibility is often outweighed by lack of awareness. More incentive for buy-back or trade-in with improved communication with customers will help gain momentum in collection.

The activities of organizations that are managing recycling, for-profit or non-profit, as well as the reselling companies are not properly streamlined. As a result, the RL process of cellphones loses efficiency at different points. A more streamlined and efficient collection system would allow vendors, manufacturers, and remanufacturers, recyclers to gain scale in order to justify investments in more advanced and larger facilities resulting in greater profit. The manufacturers, distributors, RL companies along with regulators need to take more concerted effort to avoid quality leakage and achieve greater efficiency in different steps of reverse supply chain. For example, more efficient take-back program, or greater commitment in selling used devices, or improving pre-sorting before going to shredding in order to catch more reusable phones and materials should improve RL efficiency. In addition, a stricter intervenes of regulatory bodies, whether municipal or provincial, can improve the efficiency. Although Recycle My Cell has emerged as the single biggest company to represent cellphone recycling and most of the returned cellphones are funneled into this company, but not all the provinces has approved it to act as a sole company responsible for all kinds of cellphone returns. Ontario may need similar regulations like British Columbia or Nova Scotia.

We believe that lack of education about cellphone recycling plays a huge important role behind the low rate of collections. The campaigns organized by different companies are often not visible enough to draw attention. Increased visibility in recycling campaigns and customer dialogue on the importance of recycling and reusing will encourage the collection process. Repair instead of recycling campaigns will help to increase the useful life of cellphone resulting in fewer devices in landfill.

Rapid technological advancement as well as evolution and growth of smartphones in recent years render the residual values of cellphone erase more rapidly. As a result, more and more usable cellphones are changing hands in the marketplace. This marketplace is largely unregulated adding to the complexity and uncertainty of cellphone RL.

We learned from case studies on Greentec and Orchard that businesses can position themselves in right places of RL cycle contributing to the efficiency of the process, without compromising on profitability. 
This research is qualitative. In doing this, we found it highly difficult to collect information and quality data on cellphone reverse logistics. We noticed that information is either insufficient or incomplete or data is not reliable to draw decisive conclusion. One of the reasons for this deficiency is the low number of researched performed. Therefore, we feel that more quantitative research and analysis of real life scenario is necessary about RL of cellphones. There is not much quantitative research as well on inspection and quality issues of used cellphones which is necessary to improve the reusability and collection system and more work needs to be done. We also observed that there exists a void on researches that engages the time frame when most of the technological advancement in cellphone occurred. As a result, this huge technological advancement, which in our opinion may have changed the face of RL process of cellphones due to the emergence of rapidly growing secondary market in recent years, may have been ignored as a part of the RL process. Therefore, research involving that overlooked aspect of RL is extremely important and required more than ever before. 


\section{References}

Agrawal, S., Singh, R. K., Murtaza, Q. (2015). A literature review and perspectives in reverse logistics. Resources, Conservation and Recycling. 97 76-92.

Akcali, E., Cetinkaya, S. (2011). Quantitative models for inventory and production planning in closed-loop supply chains. International Journal of Production Research. 49 (8) 2373-2407.

Argenta, A. B., Reis, C. M., Mello, G. P., Dotto, G. L., Tanabe, E. H., Bertuol, D. A. (2016). Supercritical CO2extraction of indium present in liquid crystal displays from discarded cellphones using organic acids. Journal of Supercritical Fluids. 120 95-101.

Baldé, C. P., Wang, F., Kuehr, R., Huisman, J. (2015). The global e-waste monitor - 2014, United Nations University, IAS - SCYCLE, Bonn, Germany.

Bonifacic, I. (2015). Due South: Orchard knows it's all about the network. URL: http://betakit.com/due-south-orchard-knows-its-all-about-the-network. Web accessed 2016/12/13.

Chan, F. T. S., Chan, H. K., Jain, V. (2012). A framework of reverse logistics for the automobile industry. International Journal of Production Research. 50 (5) 1318-1331.

Chopra, S., Meindl, P. (2015). Supply Chain Management: Strategy, Planning and Operation, 6th Edition, Pearson, New York.

Clift, R. (1997). The ECTEL trials. Journal of Industrial Ecology. 1 (2) 3-5.

Clift, R., \& Wright, L. (2000). Relationship between environmental impacts added value along the supply chain. Technology Forecast and Social Change. 65 281-295.

Dedrick, J., Kenneth L. K., Linden, G. (2011). The distribution of value in the mobile phone supply chain. Telecommunications Policy. 35 505-521.

Ellen Macarthur Foundation Report. (2012). In-depth - Mobile Phones. URL: https://www.ellenmacarthurfoundation.org/circular-economy/interactive-diagram/in-depthmobile-phones. Web accessed 2016/12/11.

Environment and Climate Change Canada. (2016). Mobile Device Recycling Program. URL: http://ec.gc.ca/gdd-mw/default.asp?lang=En\&n=51FBEBFD-1. Web Accessed 2016/11/24.

Fleischmann, M., Bloemhof-Ruwarrd, J. M., Dekker, R., Der Lann, E., Nunen, J. A. E. E., Wassenhove, L. N. (1997). Quantitative models for reverse logistics: a review. European Journal of Operational Research. 103 (1) 1-17. 
Franke, C., Basdere, B., Ciupek, M., Seliger, S. (2006). Remanufacturing of mobile phones capacity, program and facility adaptation planning. Omega. 34 562-570.

Geyer, R., Doctori Blass, V. (2010). The economics of cellphone reuse and recycling. International Journal of Advanced Manufacturing Technology. 47 (5) 515-525.

Geyer, R., Neira, J., Favret, L., Fuji, M., Miller, R., Mahdavi, S., Doctori Blass, V. (2006). Endof-Life Management of Cellphones in the United States. Donald Bren School of Environmental Science and Management, University of California.

Govindan, K., Soleimani, H., Kannan, D. (2015). Reverse logistics and closed-loop supply chain: A comprehensive review to explore the future. European Journal of Operational Research. 240 (3) 603-626.

Guarnieri, P., Silva, L. C., Levino, N. A. (2016). Analysis of electronic waste reverse logistics decisions using Strategic Options Development Analysis methodology: A Brazilian case. Journal of Cleaner Production. 133 1105- 1117.

Guide, V. D. R., Neeraj, K., Newman, C., Van Wassenhove, L. N. (2005). Cellular telephone reuse: The ReCellular Inc. case. In S. D. Flappe, J. O. Van Nunnen, L. N. Van Wassenhove (Eds.), Managing closed-loop supply chains. Berlin: Springer.

Guide, V. D. R., Jr., Van Wassenhove, L. N. (2009). The Evolution of Closed-Loop Supply Chain Research. Operations Research. 57 (1) 10-18.

Huisman, J. (2004). QWERTY and ecoefficiency analysis on cellular phone treatment in Sweden, TU Delft, The Netherlands. Stockholm: El-Krestsen.

Ilgin, M. A., Gupta, S. M. (2012). Remanufacturing Modeling and Analysis. CRC Press.

Integrated Product Policy Pilot Project, Stage 1 Final Report: Life Cycle Environmental Issues of Mobile Phones. (2005). Nokia Corporation. URL: http://ec.europa.eu/environment/ipp/pdf/nokia_mobile_05_04.pdf. Web accessed 2016/12/11.

Lindzon, J. (2014). Toronto startup sees billions in used iPhone marketplace. URL: https://www.thestar.com/partner_content/starbusinessclub/2014/07/29/toronto-startup-seesbillions-in-used-iphone-marketplace.html. Web accessed 2016/12/13.

Lund, R. (2012). The Database of Remanufacturers. Boston University, Boston, Massachusetts. McLaren, J., Wright, L., Parkinson, S., Jackson, T. (1999). A dynamic life-cycle energy model of mobile phone takeback and recycling. Journal of Industrial Ecology. 2 (1) 77-91. 
Moreira de Moraesa, D. G. S. V., Rochac, T. B., Ewaldd, M. R. (2014). Life cycle assessment of cellphones in Brazil based on two reverse logistics scenarios. Production. 24 (4) 735-741.

MPPI. (2008). Guidance document on the environmentally sound management of used and endof-life mobile phones. Mobile Phone Partner Initiative. Basel Convention, UNEP.

Pandian, G. P. R. R. S. (2015). Performance Evaluation of a Reverse Logistics Enterprise - An Agent-Based Modelling Approach. Electronic Theses and Dissertations. Paper 5276. 82-97.

Ponce-Cueto, E., Manteca, J. Á. G., Carrasco-Gallego, R. (2011). Reverse logistics practices for recovering mobile phones in Spain. Supply Chain Forum an International Journal. 12 (2) 104-114.

Quraishi, J. (2010). URL: http://www.motherjones.com/blue-marble/2010/11/what-happensyour-phone-when-you-recycle-it. Web accessed 2016/11/10.

Reverse Logistic Assciation. http://www.reverselogisticstrends.com/reverse-logistics.php. Web accessed 2016/11/04.

Rogers, D. S., Tibben-Lembke, R. (2001). An examination of reverse logistics practices. Journal of Business Logistics 22 (2) 129-148.

Singh, S. (2012). URL: http://thegadgetsquare.com/958/difference-between-smartphones-andfeature-phones/. Web accessed 2016/11/14.

Slade, G. iWaste. URL: http://www.motherjones.com/environment/2007/03/iwaste. Web accessed 2016/11/04.

Smith, C. 2017. URL: http://www.decluttr.com/blog/2017/04/05/how-quickly-does-your-phonedepreciate-in-value/. Web accessed 2017/06/21

Statistics Canada. (2015). Disposal of e-Waste by Province. URL: http://www.statcan.gc.ca/pub/11-526-x/2013001/t018-eng.htm. Web accessed 2016/11/24.

Taylor, B. (2014). How the smartphone defeated the point-and-shoot digital camera. URL: http://www.pcworld.com/article/2466500/how-the-smartphone-defeated-the-point-andshoot-digital-camera.html. Web accessed 2016/12/09.

U.S. Environmental Protection Agency. Fact Sheet: MANAGEMENT OF ELECTRONIC WASTE IN THE UNITED STATES. Web accessed 2016/11/04.

U.S. Environmental Protection Agency. Wastes - Resource Conservation - Common Wastes \& Materials - eCycling. Web accessed 2012/11/04. 
Velmurugan, M. S. (2016). Environmental and health aspects of mobile phone production and use: Suggestions for innovation and policy. Environmental Innovation and Societal Transitions. 21 69-79.

Voss, C., Tsikriktsis, N., Frohlich, M. (2002). Case research in operations management. International Journal of Operations and Production Management. 22 (2) 195-219.

Yeoman, I. (2012). Cannibalization, Journal of Revenue and Pricing Management, 11 (4) 353354. 